\title{
Decomposition Analysis of Rice-Based Integrated Crop Management-Farmer Field School (ICM-FFS) on Swampy Lands in Indonesia
}

\author{
Y. A. Dewi ${ }^{1 *}$, A. Yulianti ${ }^{2}$, and K. Kariyasa ${ }^{3}$ \\ ${ }^{1}$ Indonesian Center for Agricultural Technology Assessment and Development, Tentara Pelajar 10, Bogor, West \\ Java, Indonesia 16114. \\ ${ }^{2}$ Universitas Indonesia, Faculty of Socialist and Political Science, Departemen of Social Welfare, Depok, West \\ Java, Indonesia 16424 \\ ${ }^{3}$ Planning Bureau of The Ministry of Agriculture, Jl. Harsono RM No. 3 Ragunan, Jakarta, Indonesia 12550 \\ Corresponding author: yovianggita@yahoo.com
}

\begin{abstract}
Integrated Crop Management-Farmer Field School Program (ICM-FFS) was one of the Indonesian government's programs, which had been recognized to increase rice production. The successful implementation of ICM-FFS can be attributed toits impact on economic (production, productivity, and income) and social (increased adoption of rice technology, capacity and skills of farmers) aspects. This research assessed ICM-FFS implementation in swampy lands from the economic aspect. The assessment was conducted in 2012 in two swampy land areas, Riau and West Kalimantan Province. The total respondents for both areas were 159 farmers consisting of ICM-FFS participants and nonparticipants. Individual interviews using structured questionnaire was the main method in gathering primary data. The decomposition model was used to analyse data including farmers' income, production, and productivity. Productivity decomposition analysis results indicated that the program was only able to increase the productivity of paddy rice in swampy land by approximately 2.73 percent compared to technological farmers. The result of this conjecture was much lower than the result of a survey that reached 20 percent. The total increase was contributed more by the farmers who adopted the technology differences than the differences in the use of production inputs. Technological differences were manifested in the form of differences in the value of the intercept and slope, which were able to contribute as much as 88.28 percent of the total increase in productivity, while the remaining 11.72 percent was derived from differences in the use of production inputs.
\end{abstract}

Keywords: ICM-FFS, decomposition analysis, productivity, production, income, swampy lands

\section{INTRODUCTION}

Rice is still the most strategic commodity in Indonesia economically, socially, and even politically. This commodity is also related to the life and interests of the people, so that stagnation in the production growth can be a serious threat to national stability. Various efforts have been taken by the government to increase rice production. One of such efforts is the implementation of the Integrated Crop Management Farmer Field School Program (ICM-FFS).ICM-FFS has been implemented since 2007and during its implementation the program was able to increase rice production.

In West Sumatra, for example, rice production in some production centers increased by about 9.8 percent to 56.6 percent [1]. However, in practice there were still many problems such as: (1) the implementation cannot be separated from support elements [2]; (2) it required additional costs to adapt [3]; (3) the slow diffusion of technology from ICM-
FFS participants to non-participants [4]; and (4) the level of significance of the results may not be as expected if the approach was not fully applied[3].

The impact is significant to drive an increase in production and other aspects, so the the Indonesian Ministry of Agriculture identified the ICCM-FCS as one of its strategic programs. However, the challenge to ICM-FFS is the long-term impact or sustainability of adoption by former farmer field school participants [5]. The results of the implementation of ICM-FFS can be seen through the impact on the economy (production, productivity, and income) and social aspects (increased adoption of rice technology, improved capacity and skills of farmers).

Various studies to evaluate the impact of ICMFFS have been carried out. The outcomes of the assessment and evaluation of the program showed that ICM-FFS had an impact on increasing production, productivity, and revenue. Furthermore, knowing the 
contribution of the components that compose the production, productivity, and revenue will be the results of this assessment that enriches previous research.

The decomposition model can be used to determine the effect of the underlying factors that are affected by a major factor. The model is suitable to be applied to reveal the contribution of the basic factors of production, productivity, and revenue on ICM-FFS participants for later comparison with non-ICM-FFS participants. By knowing the contribution of these underlying factors, determining the success factors of ICM-FFS would be more accurate.

The other research in China shows that the decomposition model has been used to estimate the differences of productive efficiency between Chinese hybrid and conventional rice production. In that study, the decomposition model is used to derive technical, allocative, and economic efficiency of Chinese conventional rice and hybrid rice production. The result of the study in China showed the contribution of the component factors such as (1) positive relationship between efficiency and education for hybrid rice production, (2) farmer's abilities to receive and understand information relating to new agricultural technology, and (3) land size that has promoted efficiency of hybrid rice in modern agricultural areas [6].

Thus, this paper focuses on (1) analyzing factors or components of production, productivity, and income by using the decomposition model; and (2) analyzing the significant factors contributing to the production, productivity, and farmers' income between ICM-FFS participants and non-participants.

\section{RESEARCH METHODOLOGY}

\subsection{Theoretical Framework}

Numerous models can be used to analyse the economic performance of ICM-FFS including the decomposition model. This model is a mathematical technique to break down something that is aggregated into itscomponents, so it is possible to allocate the difference in the dependent variable to each independent variable [7].

This model had been used to analyze the contribution of each independent variable on income differences, production, and productivity in several studies. [7], for example, used this to analyze the impact of the communal irrigation system on rice production. [8] conducted a study of technological change in the production of sorghum to decompose productivity differences between new and traditional varieties into labor, seeds, fertilizer, and capital. [9] analyzed the impact of shelterbelts on the decomposition of peanut production in the rilands, South India.
On the other hand, [10] applied this technique to examine the sources of growth in upland rice production in Indonesia. [11] used decomposition analysis to assess the impact of the implementation of the Integrated Pest Management Farmer Field School (IPM-FFS) on rice productivity and pesticide use. [12] also decomposed changes in crop acreage into production and productivity, as well as the interaction between the two components. Meanwhile, [13] examined the contribution of each component to the growth of crops in various regions in India. In addition, [14] tried to decompose the residential energy consumption in China using the logarithmic mean Divisi a index (LMDI).

\subsection{Study Site and Respondents}

Research was conducted in two ICM-FFS sites in swampy areas, which were West Kalimantan and Riau Provinces, during April to May 2012. In each province, two representative regencies were chosen as areas of ICM-FFS. The sampling areas in West Kalimantan Province were three villages while in Riau Province, four villages were sampled. The total respondents were80 farmers for Riau Province and 79 farmers for West Kalimantan Province, so that the total respondents were 159 farmers.

\subsection{Data and Method of Data Collection}

Secondary data related to rice production and productivity in the regional level as well as information of ICM-FFS implementation were gathered from the Ministry of Agriculture while primary data were collected from farmers regarding system information within the last year for both ICMFFS participants and non-participants. Individual interviews were done using structured questionnaire as the main method to gather data and was supplemented by desk study and literature study.

\subsection{Data Analysis}

The decomposition model was used to analyze data focused on three major aspects, namely farmers' income, production, and productivity.

\subsection{Decomposition model of farmers' income}

The decomposition model of farmers' income seeks to analyze the income differences between ICM-FFS participants and non-participants. Through this model, the contribution of productivity, harvested areas, as well as price components, and the interaction among these components can be defined. Decomposition model of farmers' income can be estimated by the following equations: 


$$
I=A_{i} \cdot Y_{i} \cdot P_{i}
$$

where:

$$
\begin{array}{ll}
\mathrm{I} & \text { = gross farm income in one season (IDR-Indonesian Rupiah/farm) } \\
\mathrm{A}_{\mathrm{i}} & =\text { rice farm area (ha) } \\
\mathrm{Y}_{\mathrm{i}} & =\text { productivity }(\mathrm{kg} / \mathrm{ha}) \\
\mathrm{P}_{\mathrm{i}} & \quad \text { = price of unhusked rice (IDR) }
\end{array}
$$

Individual contribution towards income differences of this decomposition is described by following: $\mathrm{I}^{\mathrm{a}}=$ gross farm income of ICM-FFS participants

$\mathrm{I}^{\mathrm{b}}=$ gross farm income of non-ICM-FFS participants

$\mathrm{I}^{\mathrm{a}}-\mathrm{I}^{\mathrm{b}}=\Delta \mathrm{I}=$ income difference between ICM-FFS participants and non-participants

$\mathrm{A}_{\mathrm{i}}^{\mathrm{a}}=$ harvested area of ICM-FFS participants

$\mathrm{A}_{\mathrm{i}}^{\mathrm{b}}=$ harvested area of non-ICM-FFS participants

$\mathrm{A}_{\mathrm{i}}^{\mathrm{a}}-\mathrm{A}_{\mathrm{i}}^{\mathrm{b}}=\Delta \mathrm{A}_{\mathrm{i}}=$ differences of harvested area between ICM-FFS participants and non-participants

$\mathrm{Y}_{\mathrm{i}}^{\mathrm{a}}=$ productivity of ICM-FFS participants

$\mathrm{Y}_{\mathrm{i}}^{\mathrm{b}}=$ productivity of non-ICM-FFS participants

$\mathrm{Y}_{\mathrm{i}}^{\mathrm{a}}-\mathrm{Y}_{\mathrm{i}}^{\mathrm{b}}=\Delta \mathrm{Y}_{\mathrm{i}}=$ differences of productivity between ICM-FFS participants and non-participants

$\mathrm{P}_{\mathrm{i}}^{\mathrm{a}}=$ Price of unhusked rice of ICM-FFS participants

$\mathrm{P}_{\mathrm{i}}^{\mathrm{b}}=$ Price of unhusked rice of non-ICM-FFS participants

$\mathrm{P}_{\mathrm{i}}^{\mathrm{a}}-\mathrm{P}_{\mathrm{i}}^{\mathrm{b}}=\Delta \mathrm{P}_{\mathrm{i}}=$ differences of price of unhusked rice between ICM-FFS participants and non-participants

Such that the income of ICM-FFS participants can be described as:

$$
\mathrm{I}^{\mathrm{a}}=\mathrm{A}_{\mathrm{i}}^{\mathrm{a}} \cdot \mathrm{Y}_{\mathrm{i}}^{\mathrm{a}} \cdot \mathrm{P}_{\mathrm{i}}^{\mathrm{a}}
$$

Meanwhile, the income function of non-ICM-FFS participants can be illustrated as:

$$
\mathrm{I}^{\mathrm{b}}=\mathrm{A}_{\mathrm{i}}^{\mathrm{b}} \cdot \mathrm{Y}_{\mathrm{i}}^{\mathrm{b}} \cdot \mathrm{P}_{\mathrm{i}}^{\mathrm{b}}
$$

The value of $\Delta \mathrm{I}$ can be derived by using the preceding equations.

Equation (6) referred to equations (2) to (5) can be rewritten as follows:

$$
\mathrm{Ia}=(\mathrm{Aib}+\Delta \mathrm{Ai}) \cdot(\mathrm{Yib}+\Delta \mathrm{Yi}) \cdot(\mathrm{Pib}+\Delta \mathrm{Pi})
$$

This equation can be extended as follows:

$\mathrm{Ia}=(\mathrm{Aib} . \mathrm{Yib}+\mathrm{Aib} \cdot \Delta \mathrm{Yi}+\Delta \mathrm{Ai} . \mathrm{Yib}+\Delta \mathrm{Ai} \cdot \Delta \mathrm{Yi}) \cdot(\mathrm{Pib}+\Delta \mathrm{Pi})$

$\mathrm{I}^{\mathrm{a}}=\left(\mathrm{A}_{\mathrm{i}}^{\mathrm{b}} \cdot \mathrm{Y}_{\mathrm{i}}^{\mathrm{b}} \cdot \mathrm{P}_{\mathrm{i}}^{\mathrm{b}}+\mathrm{A}_{\mathrm{i}}^{\mathrm{b}} \cdot \Delta \mathrm{Y}_{\mathrm{i}} \cdot \mathrm{P}_{\mathrm{i}}^{\mathrm{b}}+\Delta \mathrm{A}_{\mathrm{i}} \cdot \mathrm{Y}_{\mathrm{i}}^{\mathrm{b}} \cdot \mathrm{P}_{\mathrm{i}}^{\mathrm{b}}+\Delta \mathrm{A}_{\mathrm{i}} \cdot \Delta \mathrm{Y}_{\mathrm{i}} \cdot \mathrm{P}_{\mathrm{i}}^{\mathrm{b}}+\mathrm{A}_{\mathrm{i}}^{\mathrm{b}} \cdot \mathrm{Y}_{\mathrm{i}}^{\mathrm{b}} \cdot \Delta \mathrm{P}_{\mathrm{i}}+\mathrm{A}_{\mathrm{i}}^{\mathrm{b}} \cdot \Delta \mathrm{Y}_{\mathrm{i}} \cdot \Delta \mathrm{P}_{\mathrm{i}}+\Delta \mathrm{A}_{\mathrm{i}} \cdot \mathrm{Y}_{\mathrm{i}}^{\mathrm{b}} \cdot \Delta \mathrm{P}_{\mathrm{i}}+\Delta \mathrm{A}_{\mathrm{i}}\right.$

.$\left.\Delta \mathrm{Y}_{\mathrm{i} \cdot} \cdot \Delta \mathrm{P}_{\mathrm{i}}\right)$

Equation 10 can be simplified as:

$$
\mathrm{I}^{\mathrm{a}}=\mathrm{A}_{\mathrm{i}}^{\mathrm{b}} \cdot \mathrm{Y}_{\mathrm{i}}^{\mathrm{b}} \cdot \mathrm{P}_{\mathrm{i}}^{\mathrm{b}}+\Delta \mathrm{I}
$$

$$
\text { where } \quad \begin{aligned}
\Delta \mathrm{I}= & \mathrm{A}_{\mathrm{i}}^{\mathrm{b}} \cdot \mathrm{Y}_{\mathrm{i}}^{\mathrm{b}} \cdot \Delta \mathrm{P}_{\mathrm{i}} \\
& +\mathrm{A}_{\mathrm{i}}^{\mathrm{b}} \cdot \Delta \mathrm{Y}_{\mathrm{i}} \cdot \mathrm{P}_{\mathrm{i}}^{\mathrm{b}} \\
& +\Delta \mathrm{A}_{\mathrm{i}} \cdot \mathrm{Y}_{\mathrm{i}}^{\mathrm{b}} \cdot \mathrm{P}_{\mathrm{i}}^{\mathrm{b}} \\
& +\Delta \mathrm{A}_{\mathrm{i}} \cdot \Delta \mathrm{Y}_{\mathrm{i}} \cdot \mathrm{P}_{\mathrm{i}}^{\mathrm{b}} \\
& +\Delta \mathrm{A}_{\mathrm{i}} \cdot \mathrm{Y}_{\mathrm{i}}^{\mathrm{b}} \cdot \Delta \mathrm{P}_{\mathrm{i}} \\
& +\mathrm{A}_{\mathrm{i}}^{\mathrm{b}} \cdot \Delta \mathrm{Y}_{\mathrm{i}} \cdot \Delta \mathrm{P}_{\mathrm{i}} \\
& +\Delta \mathrm{A}_{\mathrm{i}} \cdot \Delta \mathrm{Y}_{\mathrm{i}} \cdot \Delta \mathrm{P}_{\mathrm{i}}
\end{aligned}
$$$$
\text { effect of pure price }
$$

effect of productivity effect of harvested areas

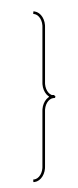
interaction terms in first order interaction terms in second order 


\section{Decomposition model of production}

The decomposition model of production can be derived from production as a result of harvested area multiplied by productivity. Therefore, there are

$$
\mathrm{Q}=\mathrm{A}_{\mathrm{i}} \cdot \mathrm{Y}_{\mathrm{i}}
$$

where $\quad: \mathrm{Q}=$ rice production $(\mathrm{kg} / \mathrm{farm})$

In partitioning the individual contribution to output difference of this decomposition let:

$\mathrm{Q}^{\mathrm{a}}=$ rice production of ICM-FFS participants

$\mathrm{Q}^{\mathrm{b}}=$ rice production of non-ICM-FFS participants

$\mathrm{Q}^{\mathrm{a}}-\mathrm{Q}^{\mathrm{b}}=\Delta \mathrm{Q}=$ rice production differences between ICM-FFS participants and non-participants

By following steps and phases in the derivation of the decomposition model of income, equation (13) can be changed into the decomposition model of production, which leads to:

$$
\mathrm{Q}^{\mathrm{a}}=\mathrm{A}_{\mathrm{i}}^{\mathrm{b}} \cdot \mathrm{Y}_{\mathrm{i}}^{\mathrm{b}}+\Delta \mathrm{Q}
$$

where:

$$
\begin{aligned}
& \Delta \mathrm{Q}=\mathrm{A}_{\mathrm{i}}^{\mathrm{b}} \cdot \Delta \mathrm{Y}_{\mathrm{i}} \\
& +\Delta \mathrm{A}_{\mathrm{i}} \cdot \mathrm{Y}_{\mathrm{i}}^{\mathrm{b}} \\
& +\Delta \mathrm{A}_{\mathrm{i}} \cdot \Delta \mathrm{Y}_{\mathrm{i}}
\end{aligned}
$$

\author{
effect of productivity \\ effect of harvested area \\ interaction term in first order
}

\section{Decomposition model of productivity}

The decomposition model of productivity was done between ICM-FFS participants and nonparticipants through variables that contributed to create differences. Supported by production function $\ln \mathrm{Y}=\ln \mathrm{a}_{0}+\mathrm{a}_{1} \ln \mathrm{N}+\mathrm{a}_{2} \ln \mathrm{S}+\mathrm{a}_{3} \ln \mathrm{C}+\mathrm{a}_{4} \ln \mathrm{F}+\mathrm{e}$, the Cobb-Douglas production function on per hectare basis transferred into log-linear form was estimated by the succeeding equations:

Production function in FFS farming:

$$
\ln \mathrm{Y}_{\mathrm{a}}=\ln \mathrm{a}_{0}+\mathrm{a}_{1} \ln \mathrm{N}_{\mathrm{a}}+\mathrm{a}_{2} \ln \mathrm{S}_{\mathrm{a}}+\mathrm{a}_{3} \ln \mathrm{C}_{\mathrm{a}}+\mathrm{a}_{4} \ln \mathrm{F}_{\mathrm{a}}+\mathrm{e}_{\mathrm{a}}
$$

Production function in non-FFS farming:

$$
\ln \mathrm{Y}_{\mathrm{b}}=\ln \mathrm{b}_{0}+\mathrm{b}_{1} \ln \mathrm{N}_{\mathrm{b}}+\mathrm{b}_{2} \ln \mathrm{S}_{\mathrm{b}}+\mathrm{b}_{3} \ln \mathrm{C}_{\mathrm{b}}+\mathrm{b}_{4} \ln \mathrm{F}_{\mathrm{b}}+\mathrm{e}_{\mathrm{b}}
$$

The differences in productivity between ICM-FFS participants and non-participants using mean values of each variable was decomposed as follows:

$$
\begin{gathered}
\Delta \mathrm{Y}=\ln \mathrm{Y}_{\mathrm{a}}-\ln \mathrm{Y}_{\mathrm{b}} \\
\ln \mathrm{Y}_{\mathrm{a}}-\ln \mathrm{Y}_{\mathrm{b}}=\left(\operatorname{lna}_{0}+\mathrm{a}_{1} \ln \mathrm{N}_{\mathrm{a}}+\mathrm{a}_{2} \ln \mathrm{S}_{\mathrm{a}}+\mathrm{a}_{3} \ln \mathrm{C}_{\mathrm{a}}+\mathrm{a}_{4} \ln \mathrm{F}_{\mathrm{a}}+\mathrm{e}_{\mathrm{a}}\right)- \\
\left(\operatorname{lnb}_{0}+\mathrm{b}_{1} \ln \mathrm{N}_{\mathrm{b}}+\mathrm{b}_{2} \ln \mathrm{S}_{\mathrm{b}}+\mathrm{b}_{3} \ln \mathrm{C}_{\mathrm{b}}+\mathrm{b}_{4} \ln \mathrm{F}_{\mathrm{b}}+\mathrm{e}_{\mathrm{b}}\right)
\end{gathered}
$$

This can be reformulated into:

$$
\begin{gathered}
\ln \mathrm{Y}_{\mathrm{a}}-\ln \mathrm{Y}_{\mathrm{b}}=\left(\ln \mathrm{a}_{0}-\operatorname{lnb}_{0}\right)+\left(\mathrm{a}_{1} \ln \mathrm{N}_{\mathrm{a}}-\mathrm{b}_{1} \ln \mathrm{N}_{\mathrm{b}}\right)+\left(\mathrm{a}_{2} \ln \mathrm{S}_{\mathrm{a}}-\mathrm{b}_{2} \ln \mathrm{S}_{\mathrm{b}}\right)+\left(\mathrm{a}_{3} \ln \mathrm{C}_{\mathrm{a}}-\mathrm{b}_{3} \ln \mathrm{C}_{\mathrm{b}}\right)+ \\
\left(\mathrm{a}_{4} \ln \mathrm{F}_{\mathrm{a}}-\mathrm{b}_{4} \ln \mathrm{F}_{\mathrm{b}}\right)+\left(\mathrm{e}_{\mathrm{a}}-\mathrm{e}_{\mathrm{b}}\right)
\end{gathered}
$$

By accumulating and subtracting some similiar variable to equation (19),

$$
\begin{aligned}
\ln Y_{\mathrm{a}}-\ln \mathrm{Y}_{\mathrm{b}}=\left(\operatorname{lna}_{0^{-}}-\ln \mathrm{b}_{0}\right)+\left(\mathrm{a}_{1} \ln \mathrm{N}_{\mathrm{a}}-\mathrm{b}_{1} \ln \mathrm{N}_{\mathrm{b}}+\mathrm{a}_{1} \ln \mathrm{N}_{\mathrm{b}}-\mathrm{a}_{1} \ln \mathrm{N}_{\mathrm{b}}\right)+ \\
\left(\mathrm{a}_{2} \ln \mathrm{S}_{\mathrm{a}}-\mathrm{b}_{2} \ln \mathrm{S}_{\mathrm{b}}+\mathrm{a}_{2} \ln \mathrm{ln}_{\mathrm{b}}-\mathrm{a}_{2} \ln \mathrm{S}_{\mathrm{b}}\right)+ \\
\left(\mathrm{a}_{3} \ln \mathrm{C}_{\mathrm{a}}-\mathrm{b}_{3} \ln \mathrm{C}_{\mathrm{b}}+\mathrm{a}_{3} \ln _{\mathrm{b}}-\mathrm{a}_{3} \ln \mathrm{C}_{\mathrm{b}}\right)+ \\
\left(\mathrm{a}_{4} \ln \mathrm{F}_{\mathrm{a}}-\mathrm{b}_{4} \ln \mathrm{F}_{\mathrm{b}}+\mathrm{a}_{4} \ln \mathrm{F}_{\mathrm{b}}-\mathrm{a}_{4} \operatorname{lnF}_{\mathrm{b}}\right)+\left(\mathrm{e}_{\mathrm{a}}-\mathrm{e}_{\mathrm{b}}\right)
\end{aligned}
$$


Then the equation was readjusted to formulate the decomposition model of productivity:

$\ln \mathrm{Y}_{\mathrm{a}}-\ln \mathrm{Y}_{\mathrm{b}}=\left[\ln \mathrm{a}_{0}-\ln \mathrm{b}_{0}\right]+$

$$
\begin{aligned}
& {\left[\left(\mathrm{a}_{1}-\mathrm{b}_{1}\right) \ln \mathrm{N}_{\mathrm{b}}+\left(\mathrm{a}_{2}-\mathrm{b}_{2}\right) \ln \mathrm{S}_{\mathrm{b}}+\right.} \\
& \left.\left(\mathrm{a}_{3}-\mathrm{b}_{3}\right) \ln \mathrm{C}_{\mathrm{b}}+\left(\mathrm{a}_{4}-\mathrm{b}_{4}\right) \ln \mathrm{F}_{\mathrm{b}}\right]+ \\
& {\left[\mathrm{a}_{1}\left(\ln \mathrm{N}_{\mathrm{a}}-\ln \mathrm{N}_{\mathrm{b}}\right)+\mathrm{a}_{2}\left(\ln \mathrm{S}_{\mathrm{a}}-\ln \mathrm{S}_{\mathrm{b}}\right)+\right.} \\
& \left.\mathrm{a}_{3}\left(\operatorname{lnC}_{\mathrm{a}}-\ln \mathrm{C}_{\mathrm{b}}\right)+\mathrm{a}_{4}\left(\operatorname{lnF}_{\mathrm{a}}-\ln \mathrm{F}_{\mathrm{b}}\right)\right]+
\end{aligned}
$$

$\left[\mathrm{e}_{\mathrm{a}}-\mathrm{e}_{\mathrm{b}}\right]$
Measures the productivity change due to shift in the intercept of the production function

\section{Measures the productivity} change due to shift in the intercept slope<smiles>[Tl]</smiles>

Measure the productivity change due to shift in the intercept of input production quantity

Calculate disparity on error terms
Decomposition analysis will be valid if the differences between ICM-FFS participants and nonparticipants composed was significantly different, so that Chow test was used prior to test the significant differences of two models (Chow 1960):

$$
\mathrm{F}_{\mathrm{c}}=\frac{\left[\sum \mathrm{e}^{2}{ }_{\mathrm{p}}-\left(\sum \mathrm{e}^{2}{ }_{\mathrm{a}}+\sum \mathrm{e}^{2} \mathrm{~b}\right)\right] / \mathrm{K}}{\left(\sum \mathrm{e}^{2}{ }_{\mathrm{a}}+\sum \mathrm{e}^{2}{ }_{\mathrm{b}}\right) /\left(\mathrm{n}_{\mathrm{a}}+\mathrm{n}_{\mathrm{b}}-2 \mathrm{~K}\right)}
$$

where:

$\sum \mathrm{e} 2 \mathrm{p}=$ unexplained variation from total production function

$\sum \mathrm{e} 2 \mathrm{a}=$ unexplained variation from total production function of ICM-FFS

$\sum \mathrm{e} 2 \mathrm{~b}=$ unexplained variation from total production function of non-ICM-FFS

na $\quad=$ total respondents of ICM-FFS

$\mathrm{nb}=$ total respondents of non-ICM-FFS

$\mathrm{K}=$ number of parameters including intercept

\section{RESULTS AND DISCUSSION}

\subsection{Harvested Areas, Production, and Productivity of Rice in Study Sites}

At the national scale, Riau Province is not one of the rice production center in Indonesia. Within 2006-2015, the average harvested area in this province was around 0.136 million ha, or its share to total area at national level of only about 1 percent. The average of its growth during 10 years was -2.22 percent each year or below the average growth in the national level $(2.09 \%)$. In addition, the average of rice production was under 0.5 million ton and the productivity was only about 35.4 quintal/ha. The negative growth of production $(-0.55 \%)$ also described the development of rice in the province, which still faces obstacles. This growth was below the average growth at the national level where the share only constituted -14.70 percent (Table 1 ).

The average growth of rice productivity was higher than its harvested area, which means the contribution of productivity was larger or it indicated that the adoption of rice technologies in farmer level was passably. But then, the productivity should be increased because of the low level of average productivity. Land aspect (agro-ecosystem) was considered as one of the major factors that cause low productivity in swampy areas as well as the aspect of technology implementation. The productivity in swampy lands was around 20-60 qu/ha, so that the performance of rice productivity in Riau still can be improved [15]. 
Table 1. Harvested area, production, and productivity in Riau, 2006-2015

\begin{tabular}{|c|l|l|l|}
\hline Year & $\begin{array}{l}\text { Harvested area } \\
\text { (million ha) }\end{array}$ & $\begin{array}{l}\text { Production } \\
\text { (million ton) }\end{array}$ & Productivity (qu/ha) \\
\hline 2006 & 0.136 & 0.429 & 0.32 \\
\hline 2007 & 0.147 & 0.490 & 0.33 \\
\hline 2008 & 0.148 & 0.494 & 0.33 \\
\hline 2009 & 0.149 & 0.531 & 0.36 \\
\hline 2010 & 0.156 & 0.574 & 0.37 \\
\hline 2011 & 0.145 & 0.535 & 0.37 \\
\hline 2012 & 0.144 & 0.512 & 0.36 \\
\hline 2013 & 0.119 & 0.434 & 0.37 \\
\hline 2014 & 0.106 & 0.385 & 0.36 \\
\hline 2015 & 0.108 & 0.393 & 0.37 \\
\hline Average & 0.136 & 0.478 & 0.354 \\
\hline Share to national level (\%) & 1.05 & 0.73 & 1.23 \\
\hline The average of growth & -2.22 & -0.55 & 1.68 \\
\hline Share to national level $(\%)$ & -106.29 & -14.70 & 104.36 \\
\hline
\end{tabular}

Source: [16] (2016; processed, for data in 2015); [17]

(2017; processed, for data from 2006-2014)

In West Kalimantan, the average harvested area in the period of 2006-2015 was 0.424 million ha and its share to national level was about 3.27 percent (Table2). Table2 shows that the average of rice production in this province was 1.306 million ton or it gave contribution slightly under 2 percentto national production, and in the same periodthe average of production growth was under the national average $(1.79 \%)$. Meanwhile, its productivity was not yet optimal which was 30.4 qu/ha or slightly below compared to Riau and average of national productivity. It caused the share to the national growth was only 3.04 percent. The growth rate of harvested area in this province was higher than its productivity or the performance of rice production was more influenced by the increase of harvested area rather than its productivity. Other than the implementation of rice technologies, which was not optimal this condition also indicated that the addition of harvested areas in this region is potential because swampy lands in West Kalimantan are very prospective to cultivate rice ([18]; [19]).

Table 2. Harvested area, production, and productivity in West Kalimantan, 2006-2015

\begin{tabular}{|c|l|l|l|}
\hline Year & $\begin{array}{l}\text { Harvested area } \\
\text { (million ha) }\end{array}$ & $\begin{array}{l}\text { Production } \\
\text { (million ton) }\end{array}$ & Productivity (qu/ha) \\
\hline 2006 & 0.378 & 1.108 & 0.29 \\
\hline 2007 & 0.399 & 1.225 & 0.31 \\
\hline 2008 & 0.424 & 1.321 & 0.31 \\
\hline 2009 & 0.419 & 1.300 & 0.31 \\
\hline 2010 & 0.399 & 1.344 & 0.31 \\
\hline 2011 & 0.444 & 1.373 & 0.31 \\
\hline 2012 & 0.428 & 1.300 & 0.30 \\
\hline 2013 & 0.465 & 1.442 & 0.31 \\
\hline 2014 & 0.452 & 1.373 & 0.29 \\
\hline 2015 & 0.434 & 1.276 & 0.304 \\
\hline Average & 0.424 & 1.306 & 61.17 \\
\hline Share to national level (\%) & 3.27 & 1.99 & 0.05 \\
\hline The average of growth & 1.71 & 1.79 & 3.04 \\
\hline Share to national level $(\%)$ & 81.89 & 48.13 & \\
\hline
\end{tabular}

Source: [16] (2016; processed, for data in 2015); [17] (2017; processed, for data from 2006-2014)

\subsection{Decomposition Analysis of Productivity, Production, and Income}

Chow test showed that production function of ICM-FFS participants and non-participants was significantly different at the level of 10 percent. Therefore, it is valid to further conduct decomposition analysis (Table 3). 
Table 3. Chow test result on rice production function in swampylands, Indonesia, 2012

\begin{tabular}{|c|c|c|c|}
\hline Description & ICM-FFS & Non-ICM-FFS & Pool Data \\
\hline$\sum \mathrm{e} 2$ (residual of the error sum squares) & 8.637004 & 0.479822 & 27.90214 \\
\hline Number of observations & 78 & 81 & 159 \\
\hline d.f. & 70 & 73 & 151 \\
\hline \multicolumn{4}{|c|}{$\mathrm{F}=2.17 *$} \\
\hline
\end{tabular}

Note: * significantly different at 10 percent probability

These were discussed successively: productivity, decomposition analysis, production, and income between ICM-FFS and non-ICM-FFS on swampylands. To enrich the discussion about ICMFFS and non-ICM-FFS farmers, t-test was employed resulting in the overview of differences between those farmers in several aspects, which included production inputs, production, productivity, and harvested area. The seed used between FFS and non-FFS farmers was significantly different at the level of 5 percent probability where FFS farmers used a less volume of seed indicating that FFS farmers already implemented the recommendation of seed quantity $(25-30 \mathrm{~kg} / \mathrm{ha})$. The quantity of urea was higher in FFS farmers than in non-FFS and it was significantly different at the level of 5 percent probability. Furthermore, this also occurred for NPK and organic fertilizer and pesticides, which were considerably diverse between
FFS and non-FFS farmers at the level of 10 percent probability. These differences also described that FFS participants tended to be more intensive in managing their farming compared to non-FFS farmers (Table 4).

As seen from Table 4, the productivity between those farmers was also notably different at the level of 1 percent probability. The average productivity of FFS farmers was 3.4 ton/ha or 20.45 percent higher than non-participants affecting a higher production by 30.2 percent (significantly different at probability level of $5 \%$ ). However, the price of unhusked rice showed a different result. Non-FFS farmers received a slightly higher price $(0.14 \%)$ than FFS respondents. In general, these outcomes reflect the concern of the ICM-FFS program on increasing productivity and production, yet the improvement of grain quality might still be neglected.

Table 4. The difference of production inputs, production, productivity, and harvested area between ICM-FFS and nonICM-FFS farmers in swampy lands, Indonesia, 2012

\begin{tabular}{|l|l|l|l|}
\hline Variable & ICM-FFS & non-ICM-FFS & Difference \\
\hline Seed (kg/ha) & 33.4 & 42.7 & $-9.3^{* *}$ \\
\hline Urea (kg/ha) & 116.0 & 93.0 & $23.0^{* *}$ \\
\hline SP36 (kg/ha) & 47.5 & 44.8 & $2.7 \mathrm{~ns}$ \\
\hline NPK (kg/ha) & 82.4 & 44.9 & $37.5^{* * *}$ \\
\hline Organic fertilizer (kg/ha) & 70.0 & 13.5 & $56.4^{* * *}$ \\
\hline Pesticides (000 IDR/ha) & 372.8 & 283.3 & $89.6^{* *}$ \\
\hline Labor (000 IDR/ha) & $4,850.8$ & $4,969.9$ & $-119.1 \mathrm{~ns}$ \\
\hline Productivity (kg/ha) & $3,444.9$ & $2,740.3$ & $704.6^{* * *}$ \\
\hline Price of unhusked rice (IDR/kg) & $3,610.9$ & $3,616.0$ & $-5.2 \mathrm{~ns}$ \\
\hline Harvested area (ha) & 1.2 & 1.0 & $0.2 \mathrm{~ns}$ \\
\hline Production (kg) & $4,322.2$ & $3,016.0$ & $1,306.2^{* *}$ \\
\hline Revenue (000 IDR) & $15,453.8$ & $10,716.6$ & $4,737.2^{* *}$ \\
\hline
\end{tabular}

Source: Primary data (processed)

Notes: *** significantly different at the level of 1 percent probability; ** significantly different at the level of 5 percent probability, * significantly different at the level of 10 percent probability; ns not significantly different at level of 10 percent probability

\subsection{Decomposition Analysis of Productivity}

The results of the analysis of the decomposition of productivity between ICM-FFS and
non-ICM-FFS farming in swampy lands are presented in Table5. 
Table5. The derivated components of productivity differences between ICM-FFS and non-ICM-FFS participants in swampy lands, Indonesia, 2012

\begin{tabular}{|l|c|c|}
\hline Variable & Sub Total & Total \\
\hline A. Technology differences & & \\
\hline 1. Intercept & -187.22 & \\
\hline 2. Slope & $189,28)$ \\
\hline Seed (X1) & -29.55 & \\
\hline Urea (X2) & 42.15 & \\
\hline SP36 (X3) & -14.58 & \\
\hline NPK (X4) & -19.49 & \\
\hline Organic fertilizer (X5) & -6.55 & \\
\hline Pesticides (X6) & -20.20 & \\
\hline Labor (X7) & 237.85 & \\
\hline B. Differences of input production use & & \\
\hline Seed (X1) & -9.42 & \\
\hline Urea (X2) & 2.70 & \\
\hline SP36 (X3) & 0.34 & \\
\hline NPK (X4) & 1.73 & \\
\hline Organic fertilizer (X5) & 5.64 & \\
\hline Pesticides (X6) & -0.23 & \\
\hline 7. Labor (X7) & -0.44 & \\
\hline Total of differences in productivity & & \\
\hline Source: Primary data (processed) & & \\
\hline & & \\
\hline & & \\
\hline & & \\
\hline & & \\
\hline
\end{tabular}

In general, the estimation results indicated that ICM-FFS of rice in swampy land has not been able to increase productivity significantly, which was only about 2.73 percent. The results of these estimates were much smaller than the observation result which reached around 20 percent. The difference was allegedly caused by inaccuracies in extracting information and examples of farmers, and the presence of multiple variables such as farm management that were not included in the model. This result was in line with the previous study of FFS in China by [20], which mentioned that FFS did not bring a significant impact towards increasing the FFS farmers' knowledge that was expected in maintaining rice production.

[21] noted that the impact of FFS on crop productivity was different crossing diverse places, gender status, education level, and land terciles. FFS implementation in Thailand using an exponential growth process showed that FFF successfully brought a significant impact on the environmental by reducing the use of pesticides; however, the impact on the economic aspect denoted by the gross margin did not occur [22]. A study on FFS potato by [23] stated that though FFS was able to enhance the knowledge of its participants, which was related to improved productivity, the impact of FFS on productivity could not be directly observed. This implies that FFS could not be considered as a factor in improving potato yield. Nevertheless, an aggregate review and analysis by [24] in five Asian countries found a promising effect of FFS cotton on increasing income by 31 percent due to higher productivity $(10 \%)$ and efficient use of pesticide (decreased by $39 \%$ ).

The limited number of respondents and coverage areas in this research were also considered causing the small figure of FFS impact on productivity. Moreover, the assessment of FFS impact on one aspect could not be used to simplify the impact of FFS for dissimilar cases. Thus, to get a comprehensive analysis, the assessment from social aspect might be included.

Nevertheless, the direction given by both the estimation and the observation was positive. The different types of technologies employed contributed in the aggregate approximately 2.41 percent, while 0.31 percent was contributed by differences in the use of production inputs. Different types of applied technology by FFS participants were less than the existing technologies. It means that variables not included in the model (e.g., farmers' technologies) had a stronger influence than the ICM-FFS technology. Therefore, the technology of ICM-FFS naturally or partially contributed negatively to an increase in production, at 187.22 percent.

However, during the implementation of the program, farmers were trained and they saw the appropriate application of technology and production inputs in the field laboratory. These led to improved application time and encouraged farmers to use inputs based on the recommended technology. The impact wase ventually improvement of ICM-FFS as indicated by the slope of the aggregate production function. It can be seen that an increase in the productivity of inputs was capable of increasing productivity by approximately 189.64 percent. This increase was driven mainly by improved labor productivity and urea; on the other hand, the productivity of other inputs contributed negatively to an increase in productivity.

Contribution of the different uses of inputs also increased the productivity of rice by approximately 0.31 percent. The higher difference in using urea, SP36, NPK, and manure was able to 
contribute positively to the increase in production. The opposite occurred for seeds, pesticides, and labor. The use of less labor contributed negatively to the improvement of productivity. Similarly, the excessive use of pesticides was no longer effective and tended to contribute negatively to productivity. Of the types of inputs, seeds gave a negative contribution both in the aspect of improvement and the differences in slope of the production function use. The same was found in pesticide inputs. Negative contribution of seed in both categories was allegedly caused by the quality of seeds received by farmers. Varieties developed in the program sometimes did not fully comply with the wishes of the farmers. On the other hand, the introduction of seeds in this program was expected to contribute significantly to increased productivity.

From the analysis of the decomposition of productivity above, it can be concluded that the program to increase rice productivity around 2.73 percent compared to technological farmers. The result of this conjecture was much lower than the results of a survey that reached 20 percent; however, both approaches had the same direction. The total increase can be attributed more to farmers who adopted the technology differences than the differences in the use of production inputs. Technological differences as manifested in the form of differences in the value of the intercept and slope were able to contribute as much as 88.28 percent of the total increase in productivity; the remaining 11.72 percent came from differences in the use of production inputs. The quality of the seeds that farmers received and the type of seed varieties did not fully comply with the wishes of the farmers caused negative input contributed to increased productivity, and it was better than marginal productivity differences (slope) and of the differences in their use. Therefore, to improve the performance of rice ICM-FFS, it is essential to improve seed supply. In addition, it provided understanding and recall among farmers on the importance of the application of integrated pest management (IPM), as well as the need to put more attention on this.

The studies conducted by [4] and [3] showed that ICM-FFS had been increasing the knowledge and skills of farmers. Another study by [25] showed that ICM-FFS had reduced the use of pesticide as well as risk of crop failure. The increase in farmers' knowledge had driven the reduction of pesticide use. Meanwhile, [26] found that ICM-FFS could increase the productivity and production at the farmer level in Central Java and West Nusa Tenggara Province, Indonesia. Successful implementation of ICM-FFS was determined by many aspects such as the need for in depth understanding of the concepts and capabilities of the entire implementers ([27];[3];[28]).

\subsection{Decomposition Analysis of Production}

In general, the production of rice by each farm household was the result of multiplying the average productivity of rice per hectare and the area of land planted with rice. Therefore, there were two variables that contributed to the differences in the resulting rice production between ICM-FFS farmers and non-ICMFFS in a single season. The results of the decomposition analysis of derivated components of differences in rice production are presented in Table 6.

Table 6. The derivated components of production differences between ICM-FFS paddy and non-ICM-FFS in swampy lands, Indonesia, 2012

\begin{tabular}{|l|c|c|}
\hline \multirow{2}{*}{ Description } & \multicolumn{2}{|c|}{ Changes } \\
\hline A. Effected by & Absolute (kg) & Percentage (\%) \\
\hline 1. Productivity & & \\
\hline 2. Harvested area & 691.4 & 51.83 \\
\hline B. Interaction term in first order & 511.2 & 38.32 \\
\hline (Productivity and harvested area) & & 9.85 \\
\hline Total & 131.5 & 100.00 \\
\hline
\end{tabular}

Source: Primary data (processed)

The results of the analysis showed that rice production of FFS participants was about 1.3 tons, higher thanthat of non-FFS farmers. The source of this difference was contributed by approximately 51.83 percent due to the improved productivity of the program,38.32 percent due to the harvested area, and the remaining 9.85 percent due to the contribution of the interaction of productivity and harvested area.

Thus, improvements in productivity relative to the technology contributed to the increase in production compared to the expansion in harvested area. The efforts to improve the performance of these programs on a continuous basis and the development of the program could be expanded in broader areas including sub optimal lands, which were expected to promote growth in rice production in Indonesia.

\subsection{Decomposition Analysis of Income}

By the same approach, the income of farmers from rice farming was the product between the interaction of production and price. For rice production, this can be obtained from the multiplication of productivity with the harvested area. Thus, there were three variables that served as sources of differences in income between FFS and non-FFS farmers (i.e., productivity, harvested area, and price).

The results of the decomposition analysis illustrated that the income of FFS farmers was around 
USD 511.5 per season, which was higher compared to the income of non-FFS farmers. This difference was effected by productivity improvements as much as 52.05 percent, which amounted to USD 266.24 (or equivalent to IDR 2.5 million), whereas expansion of planting/harvesting area contributed around 38.5 percent (USD 196.85). Meanwhile, corresponding to the previous explanation in Table 4, the price of unhusked rice negatively contributed to the income generation by -0.29 percent. The interaction of these three variables in both first and second stages was relatively small, and this tended to give a negative contribution for the variables that interacted with the price variable (Table 7 ).

Table 7. The derivated components of income differences between ICM-FFS paddy and non-ICM-FFS in swampy lands, 2012

\begin{tabular}{|l|c|c|}
\hline \multirow{2}{*}{ Description } & \multicolumn{2}{|c|}{ Changes } \\
\cline { 2 - 3 } & Absolute (USD) & Percentage (\%) \\
\hline A. Effected by & & 52.05 \\
\hline 1. Productivity & 266.24 & 38.49 \\
\hline 2. Harvested area & 196.85 & -0.29 \\
\hline 3. Price of unshelled rice & -1.48 & 9.90 \\
\hline B. Interaction term in first order & & -0.07 \\
\hline 1. Productivity and harvested area & 50.62 & -0.05 \\
\hline 2. Productivity and price & -0.38 & 0.00 \\
\hline 3. Harvested area and price & -0.28 & -0.01 \\
\hline C. Interaction term in second order & & 100.00 \\
\hline (Productivity, harvested area, and price) & -0.07 & \\
\hline Total & 511.50 & \\
\hline S
\end{tabular}

Source: Primary data (processed)

Note: USD 1 = IDR 9.391

The above conditions indicate that increased productivity was a major contributor in increasing farmers' income relative to FFS and non-FFS farmers, and this was followed by land area. Meanwhile, the price variable gave a negative contribution. This phenomenon pointed out that the development of ICM-FFS program touched many aspects of the quality of the grain produced by farmers. Therefore, in the development of the next program, aspects of quality and quantity should receive an equal share of attention. The acceptance of farmers is not solely determined by the amount of production but also by the level of prices received by farmers. Moreover, a single policy might not be effectively increasing the impact of ICM-FFS. The focus of ICM-FFS on increasing productivity and production tends to improve only one side (i.e., supply aspect). Thus, other policies in particular price policy to maintain the output price (e.g., price of grain/unhusked rice) could be taken into account. It is expected to stimulate incentives for the farmers because they will receive a higher profit and improve the attractiveness for farmers to implement ICM-FFS.

\section{CONCLUSION}

Productivity decomposition analysis results indicated that the program was only able to increase the productivity of paddy rice in swampy land by approximately 2.73 percent compared to farmers' technology (existing technology). The result of this conjecture was much lower than the result of a survey that reached 20 percent. However, the two approaches gave the same direction. The total increase could be attributed more to the adoption of technology differences than to the differences in the use of production inputs. Technological differences are manifested in the form of differences in the value of the intercept and slope, which are able to contribute as much as 88.28 percent of the total increase in productivity, and the remaining 11.72 percent was derived from differences in the use of production inputs. Seed quality and the types of varieties are not entirely suited to farmers that suspected causing a negative contribution in increasing productivity. Therefore, to improve the performance of rice ICMFFS, the improvement of seed supply becomes crucial as well as to remind farmers about the importance of applying the optimal IPM.

The results of the decomposition analysis showed that the improved productivity of the production of rice in the program contributed to the increase in rice production in the research location. Efforts to improve the performance of these programs need to be done continuously so the development of this program including those in sub optimal lands is expected to encourage growth of rice production in Indonesia.

Moreover, the results showed that the increase in revenue productivity was a major contributor in increasing the income of farmers in developing an ICM-FFS location, which was followed by the increase in harvested area. Meanwhile, the price gave negative contribution on the income of farmers as well. This indicates that the development program is linked to many aspects of the quality of the grain produced by farmers. Therefore, in the development of the next program, aspects of quality and quantity should receive an equal share of attention. The acceptance of farmers is not solely determined by the 
amount of production, but the level of prices received by farmers also determines it.

Nonetheless, the findings of this study might be different from the other assessments related to ICM-FFS. This research only focused on the impact of ICM-FFS on technical (i.e., economic) influences, yet it lacked consideration of the non-technical aspects. Therefore, in order to gain a comprehensive analysis, social aspects should be integrated with the economic side and may include the farmers' characteristics and behaviour as well as their level of knowledge and skill. Furthermore, the government can improve the dissemination and expand its assistance to farmers to promote increased adoption of this program.

\section{ACKNOWLEDGEMENTS}

The authors thank the Director of the Indonesian Center for Agriculture Assessment and Development (ICATAD) and both Directors of the Assessment Institute for Agricultural Technology (AIAT) of Riau and West Kalimantan. They would also like to thank all researchers and extensionists in ICATAD and AIAT of West Kalimantan and Riau that helped during the survey.

\section{REFERENCES}

[1] N. Hasan and R. Rifda, 'Model of icm-ffs assistances in west sumatera', 2010,www.sumbar.litbang.deptan.go.id,

Accessed: September 30, 2012.

[2] P. Anandajayasekeram, K. E. Davis, and S. Workneh, 'Farmer field schools: an alternative to existing extension systems? experience from eastern and southern africa', Journal of International Agricultural and Extension Education, vol. 14, no.1, pp. 81-93, 2007.

[3] A. Braun, and D. Duveskog, 'The farmer field school approach: history, global assessment and success stories',Background paper for the IFAD Rural Poverty Report 2011,International Fund for Agricultural Development, Rome, Italy, 2008.

[4] A. C. Rola, S. B. Jamias, and J. B. Quizon, 'Do farmer field school graduates retain and share what they learn: an investigation in iloilo, philippines',Journal of International Agricultural and Extension Education, vol. 9, no. 1, pp. 65-76, 2002.

[5] S. Yamazaki, and B. P. Resosudarmo, 'Does sending farmers back to school have an impact? a spatial econometric approach',Working Papers in Trade and Development, Working Paper 2007/03, Division of Economics, Research School of
Pacific and Asian Economics, the Australian National University College of Asia and the Pacific, Acton, Australia, 2007.

[6] X. Xiaosong and S. R. Jeffrey, 'Efficiency and technical progress in traditional and modern agriculture: evidence from rice production in china',Journal of Agricultural Economics, vol. 18, pp.157-165, 1998.

[7] S. P. Catelo, 'Decomposition analysis of the effect of communal irrigation system on rice production in cagayan region, philippines', Master's Thesis, University of the Philippines Los Baños, 1984.

[8] V. Kiresur, R. K. Pandey, and Mruthyunjaya, 'Technological change in sorghum production: an econometric study of dharwad farms in karnataka',Indian Journal of Agricultural Economics, vol. 50, no. 2, pp. 185-192,1995.

[9] V. V. Narayanan and L. J. Maynard' 'Impact of shelterbelts on groundnut production in therilands: a decomposition analysis', Paper presented at the Annual Meeting of the Agricultural and Applied Economics Association, Long Beach, California, July 2831, 2002.

[10] P. Simatupang, I. W. Rusastra, and M. Maulana, 'How to solve supply bottleneck in agricultural sector', Agricultural Policy Analysis, vol. 2, no. 4, pp. 369-392.2004.

[11] G. Feder, R. Murgai, and J. B. Quizon, 'Sending farmers back to school: the impact of farmer field school in indonesia', Review of Agricultural Economics, vol. 26, no.1, pp. 4562,2004.

[12] C. H. Thanh and B. Singh, 'Trend in rice production and export in vietnam', Omonrice 14, pp. 111-123,2006.

[13] P. K. Mehta, 'Role of crop diversification in output growth in india: a state-level analysis',IUP Journal of Agricultural Economics, vol. 6, no. 2, pp. 24-42,2009.

[14] X. Zhao, N. Li, and C. Ma, 'Residential energy consumption in urban china: a decomposition analysis', Energy Policy, vol. 41, pp. 644-653,2011.

[15] A. Abdurachman, 'Removing trauma of failure plg one million hectare', Sinar Tani, 2003.

[16] Indonesian Ministry of Agriculture, 'Agricultural statistics 2016', http://epublikasi.setjen.pertanian.go.id/downlo ad/file/281-statistik-pertanian-2016, Accessed: March 25, 2017.

[17] Indonesian Ministry of Agriculture, 'Database of agricultural statistics', http://aplikasi.pertanian.go.id/bdsp/index.asp. 2017, Accessed March 25, 2017.

[18] W. Sudana, 'Potential and prospects of swamp lands as a source of agricultural production', 
Agricultural Policy Analysis, vol. 3,no. 2, pp. 141-151,2005.

[19] I. Las, 'Green revolution for sustainable food security for the future." Sinar Tani, June 14, 2009.

[20] M. Guo, X. Jia, J. Huang, K. B. Kumar, and N. E. Burger, 'Farmer field school and farmer knowledge acquisition in rice production: experimental evaluation in china',Agriculture, Ecosystem and Environment, vol. 209, pp. 100-107, doi:10.1016/j.agee.2015.02.011,2015.

[21] K. Davis, E. Nkonya, E. Kato, D. A. Mekonnen, M. Odendo, R. Miiro, and J. Nkuba, 'Impact of farmer field schools on agricultural productivity and poverty in east africa',World Development, vol. 40, no. 2, pp. 402-413,2012.

[22] Praneetvatakul, S., and H. Waibel, 'Impact assessment of farmer field schools using a multi-period panel data model', Paper presented at the International Association of Agricultural Economics Conference, Gold Coast, Australia, August 12-18, 2006.

[23] E. Godtland, M., E. Sadoulet, and A. de Janvry, 'The impact of farmer-field schools on knowledge and productivity: a study of potato farmers in the peruvian andes',CUDARE Working Paper, Department of Agricultural and Resource Economics, University of California Berkeley, California,2003.

[24] A. Braun, J. Jiggins, N. Röling, H. van den Berg, and P. Snijders, 'A global survey and review of farmer field school experiences',Final Report,International Livestock Research Institute, Wageningen, the Netherlands, 2006.

[25] H. Van den Berg, 'IPMfarmer field schools: a synthesis of 25 impact evaluations. Wageningen, the Netherlands: Wageningen University,2004.

[26] Istriningsih and Y. A. Dewi, 'Performance of soybean's farmer field school- integrated crop management in central java and west nusa tenggara provinces, indonesia',Asian Journal of Agriculture and Development, vol. 12, no. 2, pp. 33-44,2015.

[27] E. Jamal, M. Mardiharini, and M. Sarwani, 'Dissemination process of icm-ffs rice: a lesson learned and future prospective',Journal of Agricultural Policy Analysis, vol. 6, no. 3, pp. 272-285,2008.

[28] T. T. Ngoc Chi, 'Factors affecting technology adoption among rice farmers in the mekong delta through the lens of the local authorial managers: an analysis of qualitative data', Omonrice, vol. 16: pp.107-112,2008. 